\title{
The effectiveness of using portfolio assessment in lecture by controlling mathematical logical intelligence
}

\author{
Mahayukti, G.A. ${ }^{* 1}$,Dantes, $N^{2}$, Candiasa, I.MP and Marhaeni, A.A.I.N ${ }^{4}$ \\ ${ }^{1}$ Pendidikan Matematika FMIPA Universitas Pendidikan Ganesha, Indonesia \\ 2 Program Studi Pendidkan Dasar Pascasarjana Universitas Pendidikan Ganesha Elementary \\ ${ }^{3}$ Program Studi Ilmu Pendidikan Program Pascasarjana Universitas Pendidikan Ganesha Educational \\ ${ }^{4}$ Program Studi PEP Pascasarjana Universitas Pendidikan Ganesha
}

\begin{abstract}
The purpose of this research aims to examine the effectiveness of using portfolio assessment in the integral calculus lecture after logical mathematical intelligence is controlled. The population of this research are all students in the department of mathematics education who program integral calculus courses on the 2015/2016 academic year. Samples in this research are 88 students, who were selected randomly. The data were analyzed by one-way covariance analysis. The result of this research showed that student's learning outcomes of Integral Calculus who were taught Integral Calculus with portfolio assessment, was higher than those of the students who were tought with essay assessment. The findings of this study show that using portfolio assessment is effective to improve student's learning outcomes of Integral Calculus.

Keywords: learning outcomes of integral calculus, logical mathematical intelligence, portfolio assessment.
\end{abstract}

\section{Introduction}

Assessment of the portfolio is an assessment which measure the extent of students in constructing and reflect on a task by collecting information materials relevant to the purpose and course material and the results of its construction can be assessed by lecturers in a certain period of time [1]. Kaino [2] revealed that the assessment of the portfolio provides an opportunity for the lecturer to think about what the student will do, why it should be done and assess the actions that have been done, current and expected results.. The characteristics of the portfolio assessment are consistent with De Lange's assessment [3].

Integral Calculus courses should be liked and well studied by the students and the learning process is also supposed to be going well, interesting and meaningful. Mutakin [4] provide that some of the causes difficulty studying Calculus is a lack of mastery of the concept of Differential Calculus, because in the process of learning and assessment applied still conventional. Mahayukti [5,6] reveals that the low learning outcomes of Student Calculus are caused by 1) student learning independence is still low, 2) student learning pattern is still like in high school, 3) weakness of mastery of concepts underlying Calculus,

" gustiayumahayukti@undiksha.ac.id 
4) the difficulty of students understanding Integral Calculus material because it is not supported by varied learning resources, and lecturers rarely use MFIs or mathematical software.

The assessment system used Middle Semester Exam and Final Exam after students experience the learning process, have not measured the student's capabilities comprehensively. Problems arising from inappropriate judgment can decrease the individual's motivation to learn which results in poor learning outcomes [7]. This reality suggests, there is gap between expectation and reality in Integral Calculus lectures. Learning outcomes are influenced by external factors and internal factors. According to Kaino [2], one factor that comes from outside the student is the form of assessment. Gunay [8] and Abidin [9] conducted a study using a portfolio assessment as a formative assessment and found that students whose learning using a portfolio assessment achieved higher learning outcomes than student learning outcomes using conventional assessment. However, the previous study compare between authentic assessment and paper test.

The students whose learning using the portfolio assessment achieved better learning outcomes, because they are accustomed to discipline and able to assess their own work in proving a theorem or in solving a problem. Slavin [10] states that, lecturers can not only provide knowledge to students, but students must build knowledge in their own minds. Lecturers can facilitate this process by teaching in ways that make the information meaningful and relevant for students, and by providing opportunities for students to find or apply your own ideas.

Other factors that contribute to student learning outcomes, either directly or indirectly, are students' mathematical logical intelligence. Gardner [11] states that logical mathematical intelligence is the ability associated with the use of numbers and logic effectively. Logical mathematical intelligence is required in mathematics learning that prioritizes numeracy and logic.

According to Campbell [12], logical mathematical intelligence involves components: Mathematical calculation, logical thinking, problem-solving, deductive and inductive considerations, and sharpness of patterns and relationships. While Iskandar [13] states that mathematical logical intelligence includes a person's ability to think inductively and deductively, the ability to think according to the rules of logic, understand and analyze patterns of numbers and solve problems by using the ability to think. Thus the characteristics of intelligent people logically mathematically include abilities in reasoning, sorting, think in patterns of cause and effect, creating a hypothesis, sought order conceptual or numerical patterns, and a rational outlook on life in general.

Suparta [14] said that in studying, understanding and solving math problems especially Integral Calculus which examines the theorems of integrity, the fundamental theorem of Calculus, the application of integral integral does not necessarily require logical mathematical intelligence because one of the objects in mathematics education is the theorem. While Safranj [15] said that Learners whose learning refers to mathematical logical intelligence get better results than the conventional group.

Based on the background of the problems mentioned above, this study use Posttest Only Control Group Design in Mathematics Education Department FMIPA to examine and analyze the effectiveness of portfolio assessment in improving Integral Calculus learning outcomes, after logical mathematical intelligence is controlled. 


\section{Method}

The research design used was Posttest Only Control Group Design which was held on semester Even Academic Year 2015/2016 in Mathematics Education Department FMIPA Undiksha. The population of this study are all students of the Department of Mathematics Education who were attending lectures Integral Calculus. The population consists of 153 students who are distributed into 4 (four) classes with relatively homogeneous characteristics. Through random sampling obtained class $\mathrm{B}$ and $\mathrm{C}$ as experimental group and class $\mathrm{A}$ and D as control group. Members of the sample from each group were taken randomly with the same number as many as 44 people, So there are as many as 88 samples.

The instrument used is the Integral Calculus achievement test in the form of essays, and mathematical logical intelligence test. By using the Lawshe [16] test involving 8 experts, obtained indeks content validity from the Integral Calculus achievement test of 0,95 and the logical mathematical intelligence test of 0,88 .

Results of empirical test, the 10 items are valid with reliability coefficient of 0.87 . Meanwhile, the logical mathematical intelligence tests, multiple choice with 45 items. The empirical test results show 40 items of valid question and 5 fall problems, with a reliability coefficient of 0.85 .Data were analyzed using one path one-way covariance analysis (Ancova Test).

\section{Results and Discussion}

\subsection{Results}

\subsubsection{Testing Requirements Analysis}

All requirements analysis includes a data distribution normality test, homogeneity of variance test, linearity test, and test the significance of the regression line alignment fulfilled. Therefore, continued to test the hypothesis

\subsubsection{Hypothesis Test}

The following results are presented as in Table 1.

Table 1. Tests of Between-Subjects Effects

\begin{tabular}{|l|c|r|r|r|r|}
\hline Source & $\begin{array}{c}\text { Type III } \\
\text { Sum of } \\
\text { Squares }\end{array}$ & df & $\begin{array}{c}\text { Mean } \\
\text { Square }\end{array}$ & \multicolumn{1}{c|}{ F } & Sig. \\
\hline Corrected Model & $1108,721^{\mathrm{a}}$ & 2 & 554,361 & 23,433 & 0,000 \\
Intercept & 2600,080 & 1 & 2600,080 & 109,904 & 0,000 \\
covariat & 907,710 & 1 & 907,710 & 38,368 & 0,00 \\
faktor1 & 141,894 & 1 & 141,894 & 5,998 & 0,016 \\
Error & 2010,904 & 85 & 23,658 & & \\
Total & 499771,000 & 88 & & & \\
Corrected Total & 3119,625 & 87 & & & \\
\hline
\end{tabular}


The result of analysis on line 4 (factor 1 ) shows $F$ arithmetic $=5,998$ with sig. $<0,05$. Which means there is a difference in learning outcomes Integral Calculus between students who use portfolios with students who use essay assessment, If seen from corrected average it turns out that average A1 $(76,55)$ is bigger than average A2 $(73,70)$. So it can be concluded that the learning outcomes Integral calculus of students who follow the learning with a portfolio assessment is higher than students who use the essay assessment, after logical mathematical intelligence controlled.

\subsection{Discussion}

Suparta in [10] states that logical mathematical intelligence in this case must be controlled its influence, because logical mathematical intelligence is the ability that is associated with the use of numbers and logic effectively and this intelligence is very important because it helps develop people's thinking and logic skills and deals with Mathematics especially Calculus. Supported also by Safranj in [15] who found that students whose learning refers to mathematical logical intelligence achieve better results than conventional groups.

The application of portfolio assessment in learning also helps students in solving more difficult and more complex mathematical problems [3], because mathematics could not be separated from the theorems interrelated and abstract.

Therefore, in order Integral Calculus concepts can be understood correctly, it must be through a continuous process. This means that to master high-level math, then the underlying concepts must be mastered by students. The hierarchical mathematical sciences fit the characteristics of a sustainable portfolio assessment, and students have the opportunity to assess their work through self-evaluation. Students also have the opportunity at least twice in the tasks given, So if there is a mistake the concept can be improved immediately and the student's retention of the concept is getting stronger, As revealed by Rose and Nicholl [17] that the more a person can see, hear, write or do something, the easier something is learned, so the results are also optimal.

The findings of this study are supported by the theory that, in the learning process there are two important things that must be considered by students. First, what materials are taught and how the material is delivered, it is none other than the competence given to students should be conducted with respect to the characteristics of competency to be controlled by the student and student characteristics. Given the Integral Calculus is part of a highly abstract mathematical material, The material is interconnected like a spiral and is a discipline that not only contains concepts, formulas, or principles But also contains the process by which such concepts, formulas or principles are obtained, So it takes extra effort for students to have a basic mastery of the concept well to understand and master the material in accordance with the expected competencies.

Second, how to assess or access student's learning progress. In this context, the assessment should be in accordance with the characteristics of learning achievement competency indicators. Therefore, appropriate forms of assessment are needed, and when appropriate time to access student learning progress. The most important is how the results obtained through the assessment are followed up for improved learning.

Compared to the learning process along with an essay assessment that tends to be limited and the same, then the essay assessment could not assess student competence comprehensively. Weldeana \& Sbhatu in [18] said that effective integration portfolio of evidence in learning college geometry in the instructional process helped students develop reflective thinking and other metacognitive skills and solve real-life problems that demand higher order thingking. 
So far in the course Integral Calculus at the end of the lecture students tend to be given an essay-like assessment that tends to be the same, And judging from limited material tests. Students in completing the assessment, follow the rules already given. Assessment of the given essay tends to be well structured so that it is clear the concept will be used to answer the assessment.

This causes the students do not have the opportunity to conduct self-evaluation of the work they make, they tend to use the principles or concepts that have been taught only as a solution to solving the problem so that mistakes are made they do not know, consequently the error is repeated. The application of these two assessment forms will provide different conditions and environments. This will also have an impact on understanding the concept. Learning conditions with the right assessment will make the learning process become more optimal where students can use the ability to reason optimally in solving problems and make decisions. This is in accordance with the opinion of Aiken [19] which states that the advantages of using a portfolio assessment can measure students' ability to organize, connecting his mind well, which is not easily obtained from other assessments. It is confirmed by Cakan et al [20], in that the use of portfolio assessment makes learning meaningful and can help students learn better.

The findings of this study also support by Cakan, et al in [20] groups of students who use the portfolio gained higher learning outcomes than the group that did not use the portfolio, they are also positive attitudes towards science. Meanwhile, Damirel \& Duman in [21] study revealed that the portfolio assessment has a significant effect on writing mastery. Gunes, et al [22] also revealed that the use of the portfolio assessment had a significant effect on the success of students as prospective teachers and reduced their anxiety in the learning and evaluation process. And [23] the experimental group received the treatment 1.e portfolio assessment while the control group underwent the traditional approach of writing assessment. Thefindings suggest that portfolio assessment technique improves writing ability of the students. Therefore, it is acceptable that the use of portfolio assessment in learning can improve student learning outcomes after logical intelligence is controlled mathematically.

\section{Conclusions}

Based on the results of hypothesis testing, the findings in this study is the learning result Integral calculus of students who follow the process of learning accompanied by portfolio assessment, higher than students who use the essay assessment. Thus it can be concluded that an effective portfolio assessment improves students' Integral learning calculus results, after logical mathematical intelligence is controlled. Referring to the results of research that has been stated above, the use of portfolio assessment can be developed in other subjects.

\section{References}

[1] Zainul, A. 2001. Alternative Assessment. Jakarta: UT.

[2] L. M. Kaino. Journal of Social Sciences. 5 (15). (2014)

[3] J. De Lange. 1997. Mathematics Insight and Meaning. Uttrech: OW \& OC.

[4] T.Z. Mutakin. Jurnal Formatif. III (1). 49-60 (2013)

[5] G. A. Mahayukti. Pengembangan Perangkat Pembelajaran Berbasis Masalah Berbantuan Pertanyaan-Pertanyaan Pembimbing untuk Meningkatkan Kualitas Perkuliahan Kalkulus. This article was presented in Senari (2014)

[6] G. A. Mahayukti. Pengembangan Perangkat Pembelajaran Berbasis Masalah Berbantuan Software Matematika dengan Asesmen Autentik untuk Meningkatkan 
Efektifitas Perkuliahan Kalkulus Integral dan Kemandirian Belajar Mahasiswa. This article was presented in Senari.(2016)

[7] Javanmard. Y. \& Faharani, H. "Investigating Using Portfolio Assessment and Learning English Language in Qom Secondary Schools." Global Journal of Human Social Science 12(12): 52-60.(2012)

[8] A. Gunay and F. O. Bekiroglu. EJMSTE. 10 (6). 667-680. (2014)

[9] Abidin, Z \& Walida, S. "The Model of Mathematics E-Portfolio Assessment for Senior High School." ARPN Journal of Science and Technology 10: 4-11.( 2014)

[10] R. E. Slavin. Psikologi Pendidikan : Teori dan Praktek. Jilid 2. Jakarta: Indeks. (2009)

[11] Howard Gardner, Multiple Intelligences, The Theory in Practise (New York: Basic Book, 1993).

[12] Campbell et al. Metode Praktis Pembelajaran Berbasis Multiple Intelligences. Depok: Intuisi Press. (2006)

[13] Iskandar. Psikologi Pendidikan : Sebuah Orientasi Baru. Jakarta: Referensi. (2012)

[14] I. N. Suparta. Kontribusi Pendidian Matematika Dalam Pengembangan Nilai Kemanusiaan. An Oration on Profesor I. N. Suparta for the honorary degree of Profesor of Mathematics Department, Faculty of Mathematics and Natural Sciences, Ganesha University of Education in 2014.

[15] J. Safranj. Procedia-Social and Behavioral Sciences, 232. (2016)

[16] Lawshe, C.H. 1975. "A Quantitative Approach to Content Validity." Personal Psychology. 28: 563-575

[17] Rose, C. \& Nicholl, Malcolm J. Accelerated Learning for The $21^{\text {ST }}$ Century (New York: Delacorte Press, 1997), h. 142.

[18] Weldeana, H. N \& Sbhatu, D.B. Portfolio of Evidence: An assessment Tool in Promoting Geometry Achievement Among Teacher Education College Students, 13, issue 6: 1981-2004. (2017).

[19] Aiken, L. R. 1988. Psychological Testing and Assessment. Boston: Allyn and Bacon, Inc.

[20] M. Cakan, G. Mihladiz, and Taskin. Journal of Educational Science. 2(2). 362-377. (2010)

[21] M. Damirel and H. Duman. Procedia- Social and Behavioral Sciences. 191. (2015)

[22] Gunes, M. H, Demir, S., Balaban, M. 2015. "The Effect of Portfolio Assessment Application On Academic Achievement and Test Anxiety in Teaching Animal Tissue." Necatibey Faculty of Education Electronic Journal of Science and Mathematics Education. 9. Issue 1: 1-22.

[23] Tabatabaei, O. "The effect of portfolio Assessment Techinique on Writing Performance of EFL Learnes.” English Language Teaching, 5(5): (2012). 